\title{
STÜNDL LÁSZLÓ
}

egyetemi docens

Debreceni Egyetem, Mezőgazdaság-, Élelmiszertudományi

és Környezetgazdálkodási Kar, Élelmiszertechnológiai Intézet

University of Debrecen, Faculty of Agricultural and Food Sciences

and Environmental Sciences, Institute of Food Technology

stundl@agr.unideb.hu

\section{0 ÉVES A DEBRECENI EGYETEM MEZŐGAZDASÁG-, ÉLELMISZERTUDOMÁNYI ÉS KÖRNYEZETGAZDÁLKODÁSI KARA}

Az irás áttekinti a mezögazdaságtudományi képzés debreceni történetét a Debreceni Agrártudományi Egyetem 1970-es megalakulásától az egységes Debreceni Egytem létrejöttén át napjainkig. Elötérben az oktatási tevékenység bemutatása áll jól érzékeltetve, hogy az agrármérnökképzésre épülve mennyire kiszélesedett az elmúlt öt évtizedben a szakok kinálata. Az ismertetésben kiemelt szerepet kapnak a kutatási-fejlesztési tevékenység legfontosabb eredményei és jövöbeli célkitüzései is.

Kulcsszavak: Debreceni Agrártudományi Egyetem, mezőgazdasági szakok, kutatás-fejlesztés

The School of Agriculture, Food Sciences and EnVIRonmental Management at the University of DEBRECEN TURNS 50. The paper reviews the history of agricultural education in Debrecen from the establishment of the University of Agriculture in Debrecen in 1970 to the present day. The main focus is on the discussion of educational activities, showing how the thematic range of courses has broadened in the past five decades. The main achievements and future objectives of research and innovation are also highlighted.

Keywords: University of Agricultural Sciences, Debrecen, agricultural training courses, research and innovation

Az Alföld és tágabb értelemben a Tisza vízgyűjtője hazánk agrár-élelmiszergazdaságának a központja. Ezért is logikus döntés volt elödeinktől, hogy az alapanyag-elöállítás és -feldolgozás támogatására a régióban legyen egy felsőfokú oktató és kutatóhely,

Beérkezett: 2021. 02. 15.

Közlésre elfogadva: 2021. 05. 15.

Copyright GERUNDIUM 
amely a képzett humán erőforrás folyamatos biztosításával és a tudományos eredmények gyakorlatba ültetésével segíti a versenyképes agrárium kialakítását és fenntartását.

A debreceni agrár felsőoktatás 1868-ban, a Debreceni Országos Felsőbb Gazdasági Tanintézet megalakulásával indult. 1874-1906 között Középfokú Gazdasági Tanintézet, 1944-ig Magyar Királyi Gazdasági Akadémia néven működött. Intézményünk 1945-1949 között a Magyar Agrártudományi Egyetem, Mezőgazdaságtudományi Kar Debreceni Osztálya megnevezéssel folytatta tevékenységét. 1953-ban a Debreceni Mezőgazdasági Akadémián indult újra a képzés, amely 1962 és 1970 között egyetemi szintre emelkedett az Agrártudományi Főiskolán.

Az országos agrár-felsőoktatási fejlesztés keretében, az 1970. évi 20. sz. törvényerejü rendelet intézkedett a Debreceni Agrártudományi Egyetem (DATE) létesítéséről. Az egyetemi rangú Debreceni Agrártudományi Főiskola és a szarvasi Felsőfokú Mezőgazdasági Technikum összevonásából jött létre (megfelelve annak a kritériumnak, amely szerint egy egyetem több karral rendelkezik), a debreceni kar mezőgazdaságtudományi egyetemi- (MTK), a szarvasi öntözéses-meliorációs föiskolai kar volt. 1972-ben a mezőtúri mezőgazdasági gépészeti főiskolai kar, 1976-ban a Karcagi Talajművelési Kutató Intézetet is a Debreceni Agrártudományi Egyetemhez került. 2000. január 1-jén öt egyetemi, három főiskolai karral és három kutatóintézettel megalakult a Debreceni Egyetem, így a Kar önállóan folytatta működését.

\section{Graduális oktatás}

1970-es indulásakor a DATE MTK agrármérnököket képzett. A szakirányú differenciált tanterv 1975 őszétől lépett életbe, mely szerint a hallgatók a harmadik tanévtől négy szakirányban (növénytermesztés, állattenyésztés, ökonómia és növényvédelem) folytathatták tanulmányaikat. E mellett kiegészítő képzést biztosított mérlegképes könyvelésből és növényvédelmi szaktevékenységből is. A számítástechnika oktatása az 1978/79-es tanévtől indult el.

1982-ben, a Mezőgazdasági és Élelmezésügyi Minisztérium (MÉM) az agrár-felsőoktatás képzési céljának az alábbit határozta meg:

„Az okleveles mérnökképzés célját alkalmazott természettudományos, műszaki és ökonómiai alapképzettségű, a szakterületén mélyreható ismeretekkel rendelkező, szintetizáló és innovációs képességü, tudományos igényü szakemberek képzésében határozták meg, akik a tervezési, fejlesztési, szervezési és irányítási munkában alkalmasak a tudományos eredmények gyakorlati alkalmazására, a vállalati, az ágazati stratégia kialakítására és a gazdálkodás egészét átfogó vezetői tevékenységre, tudományos kutatómunkára, illetve speciális szakterületek ellátására." Ez az elv és cél a mai napig érvényes! 
Ekkor fogalmazódott meg az igény is, hogy a teljes képzés anyaga három részből épüljön fel. A kötelező alapozó, a kötelező szakmaspecifikus és a szabadon választott tantárgyaiból, hogy a képzés sokrétűbb, rugalmasabb, a gyakorlat igényeihez jobban illeszkedő legyen. A Kar akkori oktatási küldetésnyilatkozata szerint:

\begin{abstract}
„[a]z oktató-nevelő tevékenység célja a népgazdaság, alapvetően a Tiszántúl és Észak-Magyarország termelő üzemeinek igényeit kielégítő, az agrármérnöki munkakör betöltéséhez szükséges általános szakmai műveltséggel, ezen túl egy-egy szakirányban magas szintű elméleti és gyakorlati tudással, annak alkalmazásához megfelelő gyakorlattal rendelkező, az agrármérnökre háruló feladatokat tudatosan vállaló, művelt, idegen nyelvet ismerő agrár-szakemberek képzése.
\end{abstract}

Az új irányelvek alapján készített tantervben a szigorlatok, záróvizsgák, kollokviumok, gyakorlati jegyek és megajánlott jegyek rendszere olyan képzés folytatását segítette, mely rugalmasan követte a gazdasági szereplők és a társadalom változó igényeit. A végzett hallgatók okleveles agrármérnöki diplomát kaptak, betétlapon megnevezve a választott szakirányt.

A 1993/94-es tanévtől már „A-típusư” (kötelező) természettudományi alapozó, növénytermesztési, állattenyésztési, ökonómiai és műszaki ismeretek törzstárgyak, tárgycsoportok szerepeltek. A „B” típusú (választható) tárgyakat nyolc szakirányban lehetett felvenni: állattenyésztés, biotechnika és biotechnológia, környezetgazdálkodás, mezögazdasági termékfeldolgozás és minőségvizsgálat, növényvédelem, tápanyag- és vízgazdálkodás, vállalkozásszervezés és vidéki erőforrás-gazdálkodás. Az időközben elindult a gazdasági képzés, amely eredményeként a 1995/96-os tanévtől az ún. gazdasági agrármérnöki diplomát is kibocsátottuk. A 90-es évektől a megváltozott társadalmi és gazdasági feltételek miatt az oktatás is fokozatosan átalakult. Az 1996/97-es tanévben nappali tagozaton megindult a kétéves mérnöktanár-képzés, az 1997/98-as tanévben az ötéves környezetgazdálkodási agrármérnök (1997), valamint a hároméves mezőgazdasági szakigazgatási szervezőmérnök képzés (1997), az 1998/99-es tanévben pedig levelező tagozaton a négyéves vadgazdamérnök képzés is. Majd következett a hároméves főiskolai természetvédelmi (2002), kertészmérnöki (2002), mezőgazdaságmérnöki (2003) és az ötéves egyetemi élelmiszer-minőségbiztosító- (2000), valamint az agrárkémikus agrármérnöki (2002) szakok indítása. Tanterveik alapján megállapítható, hogy az oktatás szerkezete a hosszú évek során meglehetősen bonyolult fejlődés eredményeként sokrétűvé vált, az egyetemi kar oktatási tevékenysége a diszciplínák igen széles körére terjedt ki.

Az 1998/99-es tanévtől beiratkozott hallgatók számára az államvizsgára bocsátás feltétele volt egy idegen nyelvből a középfokú „C” típusú nyelvvizsga letétele is. Az államvizsga a diplomaterv megvédéséből, a kijelölt tárgykörök vizsgáinak letételéből állt. Mind ezek eredményes zárása után kiadhattuk az okleveles agrár-, gazdasági, környezetvédelmi, szakigazgatási mérnöki, mérnöktanári, illetve vadgazdamérnöki diplomákat. 
Az agrár-felsőoktatásban jelentős változást hozott a többlépcsős képzés bevezetése (2005-2006). Az ötéves egyetemi és a három éves föiskolai szakok helyett újbóli akkreditációval bevezetésre került az alap- (BSc) és a mesterképzés (MSc). BSc szakjaink: állattenyésztő mérnöki, élelmiszermérnöki, kertészmérnöki, környezetgazdálkodási agrármérnöki, mezőgazdasági mérnöki, növénytermesztő mérnöki, természetvédelmi mérnöki és vadgazda mérnöki szakok. A nagyváradi Partiumi Keresztény Egyetemen már a 2005/2006-os tanévtől indult magyar nyelvü, mezőgazdasági mérnöki BSc, kihelyezett, levelező képzés is.

Az alapszakokra építettük a mesterszakjainkat (2008-2010), amelyek a következők voltak: az agrármérnöki, az állattenyésztő mérnöki, az élelmiszerbiztonsági és - minőségi mérnöki, a kertészmérnöki, a környezetgazdálkodási agrármérnöki, a növényorvosi, a növénytermesztő mérnöki, a természetvédelmi mérnöki szakok.

2008-ban újra akkreditáltattuk az energetikai mérnökasszisztens, a gyógynövény és füszernövény-termesztő és feldolgozó technológus, a hulladékgazdálkodási technológus, a logisztikai és műszaki menedzser asszisztens, a ménesgazda, a nemzetközi logisztikai és szállítmányozási szakügyintéző, a növénytermesztő és növényvédő technológus, valamint az ökológiai gazdálkodó felsőfokú szakképzéseinket (2 éves) is.

A Vidékfejlesztési Minisztérium és a FAO szervezésében megkötött megállapodás keretében külföldi hallgatók az angol nyelvű állattenyésztő mérnöki MSc szakon 2009 óta tanulhatnak.

Ezekben az években komoly infrastrukturális fejlesztések történtek, melyek oktatóink, kutatóink munkáját egyaránt segítették, valamint megfelelő feltételeket, igényesebb környezetet kínáltak hallgatóink számára tanulmányaik folytatásához. A campuson felépült élelmiszer-tudományi, informatikai épület mellett, folyamatosan újultak meg az „A” oktatási épület tantermei, tanszékei. 2011 októberében került átadásra az Interregionális Műszaki-, Agrár Szaktanácsadási és Továbbképzési Központ, mely akkoriban elsősorban felnőttképzési, illetve szaktanácsadási feladatokat látott el.

2015 szeptemberétől a vállalatokkal szoros együttmüködésben elindítottuk a duális képzési rendszert, mind az alapképzésben, mind a mesterképzésben. Oktatási és kutatási nemzetközi kapcsolataink folyamatosan és hatékonyan müködnek, mind az Európai Unió országaival, mind a távol-keleti országokkal, melyek az oktató- és hallgatócserén túl komoly szakmai együttműködésben is megjelennek. Kiemelkedő nemzetközi kapcsolatokkal rendelkezünk többek között az Újvidéki Egyetemmel, a Nyitrai Egyetemmel, a Nagyváradi Egyetemmel, a Kolozsvári Egyetemmel, a Temesvári Egyetemmel a Lousiana Állami Egyetemmel.

Napjainkban a Debreceni Egyetem az agrárképzési, kutatási és fejlesztési tevékenységét nevesítetten három szervezeti egységben látja el, ezek a Mezőazdaság-, Élelmiszertudományi és Környezetgazdálkodási Kar (MÉK), a Gazdaságtudományi Kar (GTK) és az Agrár Kutatóintézetek és Tangazdaság (AKIT). Mind képzési, mind kutatási tevékenységét a körforgásos biogazdaság (circular bioeconomy) modelljének megfelelően fogalmazza meg, mely az anyagok és értékek újra hasznosításán alapul, az előállított 
termék hozzáadott értékének növelésén, szolgáltatásokon, okos megoldásokon keresztül.

A klasszikus osztott mező- és élelmiszergazdasági képzési portfólió (BSc, és MSc.) mellett elindult az osztatlan ötéves agrármérnök-képzés, melyek szerkezeti és tartalmi fejlesztése az ágazati igényeknek és a képzési követelményeknek megfelelően folyamatosan történik, figyelembe véve a Debreceni Egyetem multidiszciplinaritásából eredő lehetőségiet. Új oktatási területek: a duális képzési forma, az élethosszig tartó tanulás megalapozására a probléma-alapú, kooperatív és kollaboratív oktatás módszerek, és angol nyelvü képzéseink. Hasonló elvek szerint folyik a tudományos utánpótlás nevelése a két területi doktori iskolánkban is (Komlósi, 2018).

A képzés színvonalát a hazai és nemzetközi rangsorokban elfoglalt helyünk is jelzi. Természetesen a rangsorok a minősítésnél figyelembe vett tényezők alapján eltérő súlyokat alkalmaznak, mégis mind a hazai mind a nemzetközi jegyzett rendszerekben igen jó helyen állunk. A Quacquarelli Symonds (QS) World University Rankings legfrissebb, tudományterületi rangsorában ${ }^{1}$ az agrártudományi képzés (Agriculture \& Forestry) területén, karunk évek óta előkelő helyen, 2020-ban pl. a 151-200. helyen áll.

\section{Posztgraduális képzés}

Az 1950-es évek végétől már általánossá váltak azok az ún. továbbképző tanfolyamok, amelyeken - fŏleg a téli időszakokban - növénytermesztési, állattenyésztési és üzemgazdasági szakterülettel foglalkozó mérnökök vettek részt. Az ismeretek szinten tartására kezdődött meg az ún. szakmérnök-képzés. Jelenleg a szakirányú továbbképzésben hirdetett szakjaink: 1. Precíziós mezőgazdasági szakmérnöki, 2. Természetpedagógia, 3. Halgazdálkodási-, 4. Hulladékgazdálkodási-, 5. Környezettechnológiai szakmérnök, 6. Növényvédelmi szakmérnök, 7. Térinformatika és alkalmazott távérzékelés, 8. Vetőmaggazdálkodási szakmérnök és 9 . Élelmiszerlánc nyomon követési szakmérnök/szaktanácsadó.

\section{Doktorképzés}

A Debreceni Agrártudományi Egyetem 1970-ben nyerte el a jogot a doktori cím odaítélésére. 1994-től a doktori képzést és a doktori (PhD) fokozat megszerzésének eljárását újólag szabályozták. Ma a doktori (PhD) képzés három doktori iskolában folyik. A növénytermesztési és kertészeti tudományok területén a Kerpely Kálmán Doktori Iskola, az állattenyésztési tudományokban az Állattenyésztési Tudományi Doktori Iskola, míg élelmiszertudományokan a Táplálkozás- és Élelmiszertudományi Doktori Iskola szervezi a képzést. Jelen vannak a klasszikus és korszerű precíziós mezőgazdasági

${ }^{1}$ http://www.topuniversities.com/universities/university-debrecen 
kutatási témák, ugyanakkor előtérbe kerülnek az élelmiszeripari, környezetgazdálkodási, a természetvédelmi, biotechnológiai, a technológiai jellegü, valamint az interdiszciplináris területek. A doktori iskolákba jelentkezők nemcsak a Karon végett hallgatókból kerülnek ki, jelentős a más egységekből, főként a természet- és társadalomtudományi képzést nyújtó egyetemi karokról történő jelentkezés is. $\mathrm{A} P \mathrm{PhD}$ hallgatói létszámok alakulása stabil, a kisebb fluktuáció oka a bemenetet jelentő mesterképzések iránti változó érdeklődésből fakadó létszám-változások, valamint a munkaerőpiac elszívó ereje lehet. Ennek okán, a tudományos utánpótlás biztosítása érdekében további erőfeszítéseket szükséges tenni a doktorképzés támogatására is.

\section{Tudományos utánpótlás-nevelés, tehetséggondozás}

A karon tanuló hallgatók között sok tehetséges és egy adott szakterületre tudatosan készülő fiatal található. Közülük kerülnek ki azok a hallgatók, akik tudományos diákköri munkát vállalnak, bekapcsolódnak a Debreceni Egyetem Tehetséggondozó Programjába, a Tormay Béla Szakkollégium és a Kerpely Kálmán Szakkollégium munkájába, vagy demonstrátorként ismerkednek egy adott tanszék oktató, kutató munkájával.

A Karon folyó TDK munka eredményességét és színvonalát bizonyítja, hogy a kari konferenciákon jól szereplő hallgatók, nagy számban indulnak az országos versenyeken, amelyeken nemcsak az agrár, hanem más szekcióban is sikereket érnek el. Az OTDK-án, részt vevő hallgatók 30-50\%-a rendszeresen helyezést ér el. A tudományos diákköri tevékenység hasznosan egészíti ki a hallgatók ismereteit, valamint további tudományos munkára serkenthet.

A Kar a tehetséggondozásban is jelentős szerepet játszik. Két szakkollégium segíti. A Tormay Béla Szakkollégium 2002-ben alakult tehetséggondozó program, mely a benne részt vevő hallgatók számára lehetőséget nyújt, hogy saját szakterületükön vagy érdeklődési körükön belül bővebb ismeretanyagot szerezzenek, és segíti a saját kutatómunkájuk egyre nagyobb színvonalú elvégzését. A Kerpely Kálmán Szakkollégium 2010-ben kezdte meg működését. Célja, hogy magas színvonalú gyakorlati képzéssel és szolgáltatással hozzájáruljon a Debreceni Egyetem szakemberképzéséhez, e mellett lehetőséget nyújt a hallgatók számára, hogy szakterületükön, érdeklődési területükön belül további ismeretanyagot szerezzenek, valamint a hallgatói támogatási rendszer adta lehetőségek segítségével gyakorlati kutatásokat végezzenek.

\section{A jövö feladatai az oktatásban}

Az intézmény számára kötelező feladat a hagyományok megőrzése mellett az új utak, irányok és megoldások keresése. A Debreceni Egyetem Mezőgazdaság-, Élelmiszertudományi és Környezetgazdálkodási Kar (MÉK) számára a jelenlegi demográfiai 
folyamatok, csökkenő potenciális beiskolázási adatok, hallgatói létszám mellett az egyik lehetséges út a nemzetközi piac. A képzési rendszert, a tematikát, a tananyagot ennek megfelelően kell átgondolnunk úgy, hogy egyre jobban tudjunk megfelelni a fizetőképes keresletnek. Olyan minőségben kell oktatnunk, hogy a világ másik végéről is a MÉK-re jöjjön egy külföldi diák tanulni. Jelenleg hallgatóik tíz százaléka külföldi. Az angolnyelvű oktatás szélesítésével ezt a számot tovább lehet növelni. E mellett speciális képzésekre, tudásmegosztásra van szükség. Az alaptudományok, pl. a molekuláris genetika, a sejtbiológia, a növény- és az állatélettan speciális területeinek ismerete iránt a hazai vállalkozások részéről növekvő igény mutatkozik. Oktató-kutatóhelyként, ha nemzetközi színvonalú munkát tudunk végezni, akkor az a hazai vállalkozások számára és diákjainknak is piaci előnyt jelent.

Az alap- és mester-, valamint az osztatlanképzés továbbá a szakirányú továbbképzések rendszerét kell úgy átalakítani, hogy az minél érzékenyebben reagáljon a piaci igényekre. A kétszintủ képzés lehetőséget biztosít arra, hogy a hallgatók megismerjék a keresleti oldal szereplőit és valós körülmények között szerezzenek gyakorlatot a szakterületükön. A BSc képzés hetedik féléve egy 12 hetes gyakorlat. Aktív kapcsolatra van szükség a piac szereplőivel, hogy hatékonyan működjön ez a rendszer, miközben figyelni kell arra, hogy diákjaink folytassák tanulmányaikat az MSc képzésben, majd később PhD hallgatók legyenek, mivel ők jelentik számunkra az oktatói-kutatói utánpótlás bázisát. Ennek az egyensúlynak az elérése nagyon fontos.

Az agrárfelsőoktatás átalakítása során a DE MÉK számára az osztatlan képzés komoly lehetőségeket rejt. Az ötéves agrármérnök képzés lehet az egyik kitörési pontunk. A kétszíntủ képzésben követjük a trendeket. A mester- és posztgraduális, valamint specifikus rövid idejű képzések számának növelése jobban követné a mai igényeket. Az MSc képzésekben a várható kisebb hallgatói létszám miatt a tudományos területekkel szorosabban együttműködő rendszer kialakítása szükséges. E mellett a hallgatói létszám megtartása és növelése kiemelt feladat. A jövő agrárhallgatóinak meg kell mutatni, hogy sokkal többről szól ma az agrárképzés. Precíziós technológiák, vezetőnélküli traktorok és drónos permetezés, biotechnológiai alkalmazások, stb. Ez egyre inkább a piac igénye, és ez teheti vonzóbbá a fiatalok számára az agráriumot.

Kiemelten fontos számunkra hallgatóink eredményes szereplése az Országos Tudományos Diákköri Konferenciákon. A hallgatóink felismerték azt, hogy a vállalatok a leendő munkavállalók közül azokat részesítik előnyben, akik valami iránt elhivatottak és önálló munkára képesek.

A széleskörủ gazdasági kapcsolatrendszer, a térség vállalataival, cégeivel való együttműködés biztosítja a gyakorlati képzés feltételeit. Szoros kapcsolatot tartunk fenn a munkaadói szférával, kiemelten a régió meghatározó agrárvállalkozásaival. A kihelyezett tanszékeink, Karunk gyakorlati élettel való kapcsolattartásának letéteményesei.

Elődeink jó példáját követve igyekszünk korszerű ismereteket, gyakorlatorientált tudást nyújtani a hallgatók részére, hogy a gyakorlatba kikerülve, a megkezdett úton haladva öregbítsék intézményünk és a magyar mezőgazdaság jó hírnevét. 


\section{Kutatás-fejlesztés}

Az agrártudomány területén folyó kutatási tevékenységet - hasonlóan az oktatáshoz egy-egy nemzetközileg is kiemelkedő személyiség által vezetett munkacsoport végezte. A növénytudomány (agrobotanika) nemzetközi rangú tudósa Mándy György 1970-ben elnyerte a Debreceni Agrártudományi Egyetem Növénytani és Növényélettani Tanszék vezető professzori állását. Tudományos munkáinak zöme a gazdasági haszonnövényekkel volt kapcsolatos. A természetes (ős)gyepek biológiai alapjainak feltárásában fontos szerepet játszott Vinczeffy Imre. Nevéhez füződik a rétek, a legelők gyógynövényeinek botanikai feltárása, de az 1970/1980-as években kidolgozott altalajlazitás és felülvetés módszerének eredményessége is beigazolódott. Szakmai és tudományszervező munkáságát hazai és nemzetközi elismerés kísérte, ezért 1983-ban Magyarországon elöször nemzetközi gyepgazdálkodási tanácskozás, 1998-ban pedig az Európai Gyepgazdálkodási Szövetség 17. összejövetelének adott otthont a Debreceni Agrártudományi Egyetem. Herold István 1977-ben írt Takarmányozás című, tankönyvként és korszerű kézikönyvként is kiváló életműve, valamint $A$ takarmányozás elmélete és gyakorlata (1984) című munkája, szabadalmai (hangyasavas tartósítás, Debagrám báránytáp, Intenza marhahízlaló koncentrátum) mind igazolta a Kar kiváló takarmányozási kutatásfejlesztés tevékenységét. Veress László a juhágazat terén végzett oktatói, kutatói érdemei között egy új hazai juhfajta kialakítása (a booroola merinó és a magyar merinó keresztezésével) szerepel. A szántóföldi növénytermesztés tudományának oktatása, kutatása Debrecenben, országos viszonylatban is, elismertségnek örvendett. A Kerpely-féle iskola tovább vivője Bocz Ernő alapozta meg azt a világviszonylatban is kiemelkedő termésátlag-növekedést, amelyet a hazai növénytermesztés az 1960-1980-as években ért el. Az öntözéssel kapcsolatos kutatásai új korszakot nyitottak, elterjedt az idényen kívüli öntözés.

A debreceni üzemtani iskola alapítói, Gönczi Iván, Kádár Béla és Vadász László professzorok új gazdaságirányítási rendszer bevezetését segítő, korukat megelőző korszerű ismeretanyagot dolgoztak ki, mely jelentősen hozzájárult a mezőgazdaság virágkorának kialakulásához.

A kar jelenlegi kutatási tevékenysége szorosan kapcsolódik az oktatás és a szaktanácsadás stratégiai területeihez, ezzel is biztosítva ezek integrált, harmonikus egységét. A klasszikus mezőgazdasági szakterületeken kiemelt fontosságúak a hagyományos növénytermesztési és kertészeti kutatásokban a tájökológiai feltételeknek megfelelő szántóföldi növény-, gyümölcs- és zöldségfajok és fajták, hibridek komplex vizsgálata. Az állattenyésztés és a hozzá kapcsolódó tudományterületek terén a hagyományos kutatások (sertés, baromfi, szarvasmarha, juh, hal, stb.) témakörei mellett az új interdiszciplináris területek (szaporodásbiológia, állatélettan, biotechnológia, ökológiai állattartás, stb.) kapnak egyre nagyobb figyelmet. Minden kutatási területen a figyelem a komplex problémák, az éghajlatváltozás, a környezeti, biológiai, technológiai és gazdasági fenntarthatóság elveinek érvényesítése alapvető cél. A kiemelt témák közé tartozik 
az agrárkutatások környezetvédelmi összefüggéseinek, a termékminőségre ható tényezők és paraméterek, a mezőgazdasági alap- és kiegészítő tevékenységek ökonómiai vizsgálata. A vidékfejlesztési programokba történő teljes körü bekapcsolódásával a kar szerepet vállal a regionális fejlesztések tudományos megalapozásában. Ugyancsak fontos terület a mezőgazdasági termékek, élelmiszerek minőségével, az egészséges táplálkozás tudományos megalapozásával, továbbá a minőségellenőrzéssel kapcsolatos kutatások.

A Kar meglévő humán és tárgyi erőforrásai, eddigi tapasztalatai, oktatási és szaktanácsadási tevékenysége, valamint a régió adottságai/erősségei alapján egyértelműen a különleges minőségű élelmiszerek fejlesztése, a precíziós agro-technológiák a mezőgazdasági eredetủ megújuló energiaforrások, az agrár-környezetvédelem, valamint a több prognózis szerint is egyre nagyobb hatású klímaváltozás és az ehhez való alkalmazkodás területén folytat $\mathrm{K}+\mathrm{F}$ tevékenységet. E területeken - az adott kutatási feladat és finanszírozás jellegének megfelelően - a Kar minden tanszéke/intézete integrált módon bekapcsolódik (biológiai/genetikai alapok, tápanyag ellátás, technológia-fejlesztés, környezeti-, fenntarthatósági-, etikai- minőségbiztosítási és nyomon követhetőségi aspektusok, stb.). Ugyancsak szempont, hogy ezeken a területeken végzett magas színvonalú kutatási és fejlesztési tevékenység számot tart a régióban tevékenykedő vállalkozások érdeklődésére, sőt akár nemzetközi szinten is generálhat közös projekteket.

A precíziós gazdálkodás, biotechnológia, távérzékelés, növényvédelmi előrejelzések a növénytermesztésben, a szaporodásbiológia, asszisztált reprodukció, proteomika és metabolomika az állattenyésztés területén, a nutrigenomika, mint a táplálkozás, illetve élelmiszertudomány határa, azon szegmensek, amelyek egyre nagyobb szerepet játszanak az agráriumban. Magyarországon nagyon kevés az olyan vállalkozás, amely fejlesztési igényeit saját kutatócsoporttal és eszközrendszerrel oldja meg. Célunk, hogy a többségnek mi legyünk a tudományos, szolgáltató, szaktanácsadói háttér. Ez költségkímélő módszer az élelmiszerlánc szereplői számára, nekünk pedig motiváció a folyamatos, korszerü tudásszerzésre és -átadásra.

A kutatásszervezési tevékenység alapvetően az akkreditált doktori iskolák köré szerveződik. Jelen vannak a klasszikus és korszerű precíziós mezőgazdasági kutatási témák, ugyanakkor előtérbe kerülnek az élelmiszeripari, környezetgazdálkodási, a természetvédelmi, biotechnológiai, a technológiai jellegü, valamint az interdiszciplináris területek.

Az elmúlt öt évben 84 oktatási, K+F és infrastruktúra-fejlesztési projektet valósítottunk meg, melyek között hazai és nemzetközi finanszírozásúak is szerepeltek, valamint érintették az alap- és alkalmazott tudományterületeket is. Ezek eredményeként korszerüsödött a $\mathrm{K}+\mathrm{F}$ infrastruktúra (élelmiszeripar, analitika, távérzékelés, növénytermesztés és állattenyésztés) és a humán erőforrás kompetenciái is fejlődtek. Karunk jelenleg 12 innovációs és $\mathrm{K}+\mathrm{F}$ (GINOP), valamint négy oktatási és kompetencia-fejlesztési (EFOP) projekt megvalósításában vesz részt.

Korábbi fejlesztések és folyamatban lévő projektek eredményeként megvalósult egy korszerű oktatási és kutatási infrastruktúra-fejlesztés a gyakorlatorientált képzés érdekében: közel 1,5 Mrd forint támogatásból megújult épületek, új fejlesztések (kísérleti 
üvegházak, növény-tenyészház, állatház - műtővel, félüzemi recirkulációs halnevelő rendszer, NÉBIH engedéllyel működő élelmiszerüzem - tej, hús, zöldség-gyümölcs, malom, sütő és száraztészta-üzemegységekkel) és több, mint 150 nagyműszer és eszköz beszerzése történt 2015-2019 között.

\section{Jövöbeni feladataink a kutatás-fejlesztés és innováció területén}

A felsőoktatás szerepében hangsúlyeltolódás figyelhető meg: a tevékenységi körben az oktatás mellett egyre nagyobb szerepet kap a kutatási tevékenység, melyet számos korábbi koncepció és program is támogatott (pl. kutatóegyetemek támogatása, vállalkozó egyetemek kialakítása). E mellett a gyakorlattal (hazai és külföldi vállalkozásokkal, kutatóhelyekkel) kialakítandó szorosabb kapcsolatok és az egyre markánsabban megjelenő hatékony forrásfeltárás és forrásszerzési igény (saját- vagy pályázati bevétel) miatt is szükséges a meglévő humán- és tárgyiasult erőforrások és szakmai tapasztalatok egységes rendszerbe foglalása.

Napjaink egyik legnagyobb kihívása, hogy a mezőgazdaság megfelelő mennyiségű és minőségü, valamint biztonságos és nyomon követhető takarmány-, valamint élelmiszer alapanyagot állítson elő. Az élelmiszeripar jelenlegi helyzetében elsődleges fontosságú a korszerű feldolgozási technológiák honosítása, fejlesztése, a K+F eredmények hasznosítása azért, hogy a lakosságot helyi alapanyagokból készülő és fenntartható módon feldolgozott élelmiszerekkel lehessen ellátni. Az egyetem kiemelt célja a régió élelmiszeripara és mezőgazdasága versenyképességének növelése, az élelmiszergazdaság területén aktív kutatócsoportok, gazdasági szereplők és civil szervezetek együttmüködésének támogatásán, közös hálózatok, szervezetek kialakításán és új projektek létrehozásán keresztül.

A MÉK fejlesztési stratégiájának középpontjában egyebek mellett a műholdas, illetve légifelvételekre alapozott termésbecslés, növényvédelmi előrejelzés, folyamatosan mért talaj-, növény- és légköri adatokra alapozott víz- és tápanyag gazdálkodás, valamint a térinformatikai alapú big data adatkezelés szerepel. A Debreceni Egyetemen megvannak ezen területek fejlesztésének lehetőségei. Az egészségügyi, a műszaki, az informatikai, a természettudományi karokkal összekapcsolódó kutató és tudományos munka adja a rendszer interdiszciplinaritását. A mezőgazdaság ma valóban egy tudásintegráló terület. A Debreceni Egyetemen felhalmozott tudásanyagot, potenciált felhasználva bátran tervezhetjük a kar jövőjét.

A kutatás-fejlesztés terén az alábbi fókuszterületek érdemelnek kiemelt figyelmet:

- Különleges minőségü, egészségre kedvező hatású élelmiszerek fejlesztése: A program célja nagy tömegeket érinto, ún. „népbetegségekben” szenvedo (magas vérnyomás, szív- és érrendszeri problémák, diabetes, stb.) betegek számára fejleszteni speciális élelmiszereket, termékcsaládokat. 
- Erőforrás-hatékony („precíziós”) talajművelési, növénytermesztési és állattenyésztési technológiák fejlesztése, amely kiterjed a termőhely- és fajtaspecifikus precíziós növénytermesztési és integrált növényvédelmi technológiák fejlesztésére és a precíziós állattenyésztés elemeinek fejlesztésére a környezetileg és gazdaságilag fenntartható biztonságos termékelőállításért.

- Agrár-környezetgazdálkodás szempontjainak (integrált vízkészlet gazdálkodás, ökoszisztéma-, biodiverzitás- és élőhely-védelem) integrálása a mezőgazdasági termelésbe: ide kerültek besorolásra a biodiverzitás fenntartásával és gazdagításával, valamint a hazai őshonos fajták génmegőrzésével, a vad- és halfajokkal kapcsolatos elemek is, mint pl. állapot-monitoring, diverzitás felmérés.

- Mezőgazdasági eredetű megújuló energiaforrások alkalmazásának támogatása: a program az energetikai célú biomassza eloállitás földhasznosítási, növénytermesztési, előállítás-technológiai és ökonómiai kérdéseit öleli fel.

- Klímaváltozáshoz (felmelegedés, az időjárási szélsőségek, a szárazodás, szárazság és aszály) alkalmazkodó energiatakarékos, környezetkímélö, a kedvezőtlen hatást mérséklő technológiák fejlesztése.

A fentiekhez kapcsolódóan kiemelendő, hogy a kutatási területeknek hosszabb távon igazodniuk kell a képzési palettánkhoz, mely különösen vonatkozik a mester- és doktoranduszképzésre.

Különbséget kell tenni az alap és alkalmazott kutatásokkal szemben megfogalmazott elvárások esetében. Előbbinél a cél a színvonalas tudományos közlemények megjelentetése, valamint az alkalmazott kutatás és kísérteti fejlesztés támogatása. Az alkalmazott kutatások eredménye viszont szabadalom formájában, vagy spin-off cégeken keresztül kell megjelenjen, amely végül értékesítéssel árbevételt jelent.

\section{A Debreceni Agrártudományi Egyetem (DATE) és a Mezögazdaságtudományi Kar (MTK és jogutódjainak) vezetése 1970-töl napjainkig}

Az első rektor Ács Antal volt, majd 1977-től 1983-ig Tóth József vezette az intézményt. 1983-ban Tóth József megbízatásának lejárta után a kibővített egyetem vezetését Szász Gábor látta el 1983-1989 között rektorként, 1989-92 között pedig rektorhelyettesként. Az 1990-től 2000-ig terjedő időszakban Kozma András, majd Loch Jakab és Csizmazia Zoltán rektorok vezették a DATE-t. Ekkor alakult meg a Debreceni Universitas egyesülés, majd az egységes Debreceni Egyetem. 
A Debreceni Agrártudományi Egyetem Mezögazdaságtudományi Kar vezetöi (1970-2000)

1970-1974 Dr. Kádár Béla dékán, Dr. Orbán Sándor, Dr. Szász Gábor és Dr. Kiss István dékánhelyettesek

1974-1977 Dr. Sziki Gusztáv dékán, Dr. Pethő Menyhért, Dr. Szász Gábor dékánhelyettesek

1977-1980 Dr. Pethő Menyhért dékán, Dr. Szász Gábor Dr. Loch Jakab dékánhelyettesek

1980-1986 Dr. Loch Jakab dékán, Dr. Bánszki Tamás, Dr. Kozma András dékánhelyettesek

1986-1989 Dr. Kozma András dékán, Dr. Lakatos Dénes, Dr. Mirkó Lajos dékánhelyettesek

1989-1990 Dr. Supp György dékán, Dr. Lakatos Dénes, Dr. Szarukán István dékánhelyettesek

1990-1993 Dr. Nagy Géza dékán, Dr. Mihók Sándor, Dr. Győri Zoltán dékánhelyettesek

1993-1997 Dr. Nagy Géza dékán, Dr. Berde Csaba, Dr. Nábrádi András dékánhelyettesek

1997-2000 Dr. Nábrádi András dékán, Dr. Kátai János, Dr. Gonda István, Dr. Kárpáti László dékánhelyettesek

\section{A Debreceni Egyetem Mezögazdaságtudományi Kar I}

Mezögazdaság-, Elelmiszertudományi és Környezetgazdálkodási Kar vezetöi (2000-)

2000-2004 Dr. Pepó Péter dékán, Dr. Kátai János, Dr. Jávor András dékánhelyettesek 2004-2008 Dr. Kátai János dékán, Dr. Juhász Lajos, Dr. Tamás János dékánhelyettesek 2008-2012 Dr. Kátai János dékán, Dr. Komlósi István, Dr. Tamás János dékánhelyettesek

2012-2019 Dr. Komlósi István dékán Dr. Juhász Csaba Dr. Stündl László dékánhelyettesek

2019. 07. 01.-2020. 03. 29.

Dr. Bánáti Diána dékán, Dr. Sipos Péter, Dr. Stündl László, Dr. Kovács Béla dékánhelyettesek

2020- Dr. Stündl László dékán, Dr. Veres Szilvia, Dr. Sipos Péter, Dr. Kovács Béla dékánhelyettesek 


\section{Felhasznált irodalom}

Debreceni Egyetem (2011): A Debreceni Egyetem alapító okirata. Hatály: 2011. IX. 9. Frissítve: 2020. szeptember 17. 10:24

KomLósı István. „A debreceni agrárfelsőoktatás első 150 éve. Gerundium - Egyetemtörténeti Közlemények 9, 4. sz. (2018): 161-170.

Orosz István és ifj. BarTa János, szerk. A Debreceni Egyetem története 1912-2012. Debrecen: Debreceni Egyetemi Kiadó, 2012.

SURÁNYI Béla. „A magyar mezőgazdasági szakoktatás története 1945-ig, különös tekintettel a debreceni agrár-felsőoktatásra”, Gerundium - Egyetemtörténeti Közlemények 9, 1. sz. (2018): 81-115.

SuRÁNYI Béla. „Fejezetek a debreceni gazdasági és agrár felsőoktatás történetéből 1868-2018”. In 150 éves a debreceni felsöfokú agrárképzés, szerkesztette Kovács Istvánné és Mocsáriné Fricz Julianna és Komlósi István, 9-35, Debrecen, 2018. 